\title{
IMPACTO DEL COVID-19 EN LOS PROGRAMAS DE SEGUROS Y LAS PÓLIZAS VIGENTES
}

\section{IMPACT OF COVID-19 ON INSURANCE PROGRAMS AND VALID INSURANCE POLICIES}

\author{
Tomado del Boletín Informativo de Posse Herrera Ruiz*
}

Las circunstancias sociales y económicas derivadas de la epidemia de COVID-19 sin duda generarán un impacto importante sobre los programas de seguros de las compañías, las pólizas de seguros de vida, los seguros de cumplimiento en contratos a gran escala entre otros. La situación actual genera un gran número de preguntas y por ahora pocas respuestas. En relación con los seguros de vida, ¿están las muertes ocasionadas por el virus cubiertas por los seguros de vida? En general salvo que las pólizas excluyan de manera expresa las pandemias, el seguro de vida debería cubrir dicha circunstancia. De otra parte ¿Los seguros de salud contratados por las compañías para sus colaboradores cubren el tratamiento por coronavirus? Un aspecto importante de analizar es si las consecuencias adversas derivadas de actos de autoridad (restricciones a la movilidad y a las reuniones, cierre obligatorio de establecimientos de comercio, toques de queda), están cubiertas por los seguros de cumplimiento. Y más aún, si el lucro cesante derivado de tales circunstancias quedaría amparado por las pólizas que ofrecen cobertura al lucro cesante, en el entendido de que tal cobertura solo cubre el lucro cesante derivado de un daño material amparado bajo la misma póliza. Otro tema que ha generado dudas importantes es si el incumplimiento de contratos por razones atribuibles a la epidemia o a medidas del gobierno están o no amparados por los seguros de contratos, advirtiendo que es muy frecuente que los actos de autoridad estén excluidos expresamente de las coberturas. En este análisis también es muy importante revisar las cláusulas del contrato asegurado para analizar si ante el evento de incumplimiento se pueden o no invocar las cláusulas de exoneración de responsabilidad del contrato, en cuyo caso la póliza de seguro no se vería afectada. El análisis sobre estos asuntos debe partir necesariamente del texto de las pólizas, sus coberturas y exclusiones, por lo que es muy importante que el análisis de coberturas se haga caso a caso. $\mathrm{Y}$ en cualquier caso es fundamental adoptar las medidas y efectuar las notificaciones a las entidades aseguradoras dentro de los plazos señalados por la ley y el respectivo contrato de seguros.

\footnotetext{
" Tomado de: http://www.phrlegal.com/publicacion/covid-19-seguros-20-de-marzo/.
} 